\title{
Research and Exploration on Innovation and Entrepreneurship Education in Applied Local Universities
}

\author{
Jian $\mathrm{LI}^{1,2}$, Ming-Ming $\mathrm{NI}^{3}$ \\ ${ }^{1}$ School of Economics \& Management, Xi'an University, Xi'an, 710065, China \\ ${ }^{2}$ School of Economics\& Management, Northwest University, Xi'an, 710127, China \\ ${ }^{3}$ School of Economics\& Management, Shanxi University OF Science \& Technology, Xi'an, 710021
}

Email: lijian@xawl.edu.cn

Keywords: Local universities, Innovation and entrepreneurship education, Countermeasures.

\begin{abstract}
The advent of knowledge-based economy not only brings opportunities for the rapid development of the economy, but also makes our country and society facing the challenge of shortage of innovative application talents. After many years of development, innovation and entrepreneurship education has become a hot topic in college education. At present, in the process of carrying out innovation and entrepreneurship education, many colleges and universities have encountered a series of problems such as shortage of funds, insufficient teachers, curriculum setting problems and lack of the practice platforms. Through the research on the status quo and problems of innovation and entrepreneurship education $\mathrm{f}$ in applied local universities, the writer puts forward some countermeasures and suggestions in this paper, such as changing educational concepts, establishing curriculum system, establishing long-term mechanism, expanding practice base, strengthening teachers and so forth.
\end{abstract}

\section{Introduction}

At present, the promotion of innovation and entrepreneurship education has become an important tool in the comprehensive reform of education. The paper titled "Opinions on Promoting Innovation and Entrepreneurship Education in Colleges and Universities and the Work of Self-employment for College Students" was proposed by the Ministry of Education. Which emphsised that the combination of innovative education and entrepreneurship education has a very important significance in guiding for entrepreneurship education in colleges and universities ${ }^{[1]}$.Application-oriented local colleges are oriented towards local economic development. With the goal of cultivating high-quality applied talents that meet the needs of local societies and possess innovative entrepreneurial spirit, it is of great significance to vigorously carry out innovation and entrepreneurship education. At present, many applied local colleges and universities have already begun the exploration of innovation and entrepreneurship education. However, due to various factors, the innovation and entrepreneurship education in most of the application-oriented universities in China not only started very late but developed very slowly. Which is very inconsistent with the requirements of economic and social development. It is of great theoretical and practical significance to study the development and existing problems of innovation and entrepreneurship education in local universities.

\section{Organization of the Text}

\section{The Connotation of Innovation and Entrepreneurship Education in Applied Local Universities}

Foreign countries have early entered the stage of popularization of higher education, but the data shows that there is not a specific concept of "application-oriented local colleges and universities" in foreign country. The research on the development of similar institutions in foreign countries is more concentrated on the vocational colleges. In 1998, Gong Zhenwei first proposed the "Application undergraduate". In China, the study of "applied undergraduate education” has not been long, mainly 
after 2002. Regarding the connotation of "application-oriented undergraduate education", scholars have different views and opinions. It is generally believed that: Application-oriented undergraduate education is a four-year education with the goal of cultivating high-level applied talents [2]. It is more emphasison the basic education and further development than the junior colleges, and more emphasis on application and skills than regular undergraduate courses [3]. The comparatively representative definition of entrepreneurship education is that it refers to the education system that finally enables the educated to have a certain entrepreneurial ability by cultivating people's entrepreneurial awareness, entrepreneurial thinking, and entrepreneurial skills[4]. The requirements for innovation and entrepreneurship education are even higher. It refers the "double-creation education", which means to adapt the needs of social development and national strategic planning, to develop a new teaching concept and mode of cultivating entrepreneurial consciousness and pioneering talents ${ }^{[5] .}$

Applied local universities are mainly focus on the local economy, relying on the disciplines, with the professional education as the foundation, with the social demand as the orientation, to combine the entrepreneurship education, innovation education with the professional education. It enables the students to recognize themselves and their lives, to devlope a correctself-awarenessto promote their innovation and dedication. spirits by developmening the new teaching models and focusing on the quality of practical activities. At the same time, it will provide high-level human resources for the development of society and economy to cope with the challenges of the knowledge economy and global integration, it will constantly improve the quality of higher education and pluralistic orientation, to promote the development of students to maximine [6].

\section{The Status Quo of Innovative and Entrepreneurship Education in Applied Local Universities}

The applied local universities, as an applied talent training base, have gradually realized the importance and necessity ofgthe innovation and entrepreneurship education. They have already on the path to devolope the innovation and entrepreneurship education, but due to the restriction of various factors, the current status quo is not satisfying, mainly reflected in the following five aspects:

\section{Started late and develop slow}

The predecessors of most applied-type undergraduate colleges are higher vocational colleges and teachers colleges. The history of undergraduate education is relatively short, the educational conditions, such as , the teachers' strength and teaching system have no advantages compared with the old universities., and the schools are also at a disadvantage in geographical position. Therefore, applied undergraduate colleges and universities are far behind of some domestic key university, they also develop very slowly, actually, most of them are in their infancy on the basis of innovation entrepreneurship education due to the constraints in school funding, policy support, and faculty srtenth.

\section{In a Sufficient in fund and Policy Gurantee}

Most of the applied-type undergraduate colleges and universities are still in the initial stage in their innovation and entrepreneurship education. They have not developed a set of perfect policies and systems to guarantee their operation, what's more, they are not active invest in the innovation and entrepreneurship education because they cannot have immediate effect.

\section{Lack of Education Form and Content Innovation.}

With the national attention and the schools' development needs, local universities have actively carried our exploration and practice in innovation and entrepreneurship. Some colleges and universities have formed their own unique experiences and models, but, on the whole, there are still many problems in the form and the education jninnovation content. On the one hand, the form of innovation and entrepreneurship education are mainly instructive lectures, seminars and other indoctrination-based traditional teaching means and methods. This type of teaching is mainly purposed to complete the teaching tasks, which is not popular with the students and will not 
effective; on the other hand, The content of innovation and entrepreneurship education is biased towards various types of government policies, basic theories of innovation and entrepreneurship, and case sharing. Students lack an experiential learning link.

\section{Insufficient Teachers}

The local universities of applied type are not only insufficient in the preparation of innovation and entrepreneurship education teachers, but most of the teachers have high academic qualifications, but they lack experience and training in practical departments such as government and enterprises, and the knowledge structure is difficult to meet. The full range of theoretical and practical requirements. According to incomplete statistics, at present, at least $41 \%$ of the two institutions in China do not have full-time teachers engaged in entrepreneurial education [7]. Although some colleges and universities have entrepreneurial tutors, most of them are schoolteachers in economic management majors. Academic staff and external part-time tutors are obviously insufficient. Entrepreneurship education requires teachers not only to have the basic knowledge of economics, management, and entrepreneurship, but also to understand the main theories of sociology and psychology, and to have the ability to start a business. It is best to have an entrepreneurial experience, so that the theory can be linked to reality and a vivid image. To conduct entrepreneurial classroom teaching. Most of them learn about entrepreneurial knowledge and entrepreneurial experience from books and others, and they do not have the ability to translate entrepreneurial knowledge into practice. It is difficult for students to be convinced by the kind of teaching methods on paper and lack of practical operations.

\section{The Lack of a Practical Platform}

The application of undergraduate institutions due to lack of capital investment, system security is not in place, the investment in innovation and entrepreneurship education practice platform is not enough, the construction of the campus incubator base is not perfect or the utilization is not high, while the lack of off-campus practice base. Students often stay at the theoretical level and lack the experience and practice platform. This is an important reason for the low effectiveness of innovation and entrepreneurship education.

\section{Countermeasures and Suggestions on the Development of Innovative and Entrepreneurial Education for Undergraduates in Applied Local Universities}

\section{Change ideas, Establish a Scientific Concept of Innovation and Entrepreneurship Education}

The State implements the College Student Innovation and Entrepreneurship Education Program to create the most creative and innovative generation of highly qualified personnel. Therefore, universities, local governments, and all levels of society must establish the scientific concept, and make concerted efforts for college students' innovation and entrepreneurship education to provide human resources for the construction of an innovative country. As an applied-type undergraduate college, in the process of implementing innovation and entrepreneurship education, it is necessary to clearly understand that the essence of innovation and entrepreneurship education is quality education. "Education" is the fundamental goal, and the core is to cultivate students' sense of innovation, entrepreneurial ability and practical ability. Ultimately, it is the cultivation of students' overall quality.

\section{Establish a Sound Innovation and Entrepreneurship Curriculum System}

The purpose of the establishment of the application-oriented colleges and universities is to cultivate high-quality applied talents. With the society's higher and higher requirements for the innovative connotation of high-quality talents, the application-oriented colleges and universities should formulate innovation and entrepreneurship education courses. According to the requirements of social development, combining the training of disciplines and the needs of students' physical and mental development, based on professional education, innovation and entrepreneurship education is integrated into subject education and professional education, and both professional proficiency and innovation in entrepreneurship are fostered. Talents who solve complex and complex problems. 
When formulating the curriculum, students' professional characteristics, thinking characteristics, and personality characteristics are fully taken into account. At the same time, traditional teaching methods should be changed to improve students' initiative and participation in the classroom and effectively improve classroom efficiency. In addition, innovation and entrepreneurship education also has the vision of internationalization. The courses established must be combined with the development of internationalization, the progress of the times, and the development of society.

\section{Accelerate the Establishment of a Long-Term Operating Mechanism for Innovation and Entrepreneurship Education}

At present, a common problem in the innovation and entrepreneurship education of applied undergraduate colleges and universities is that there is no established or perfect innovation and entrepreneurship education management platform, resulting in the whole school does not form a joint force. Schools should incorporate innovation and entrepreneurship education into the school's important agenda and establish a standardized, scientific, and systematic management platform. An independent innovation and entrepreneurship education and research department is established to be responsible for the implementation and management of innovation and entrepreneurship education, such as the formulation of an implementation plan for innovation and entrepreneurship education, and is responsible for the organization, guidance, supervision, coordination, and management of innovation and entrepreneurship education activities. The personnel department, the Academic Affairs Office, the Youth League Committee, the Student Affairs Division and other functional departments and the secondary colleges are responsible for organizing the implementation of the small unitized innovation and entrepreneurship education management and service work, forming a "multi-participation" coordination mechanism for innovation and entrepreneurship education, integrating the use of various sectors of education. Resources to ensure the smooth implementation of innovation and entrepreneurship education work to achieve the maximum effect.

\section{Expand the Practice Base for Off-campus Innovation and Entrepreneurship Education}

A mature platform for innovation and entrepreneurship education needs the support of a number of off-campus practice bases. The ultimate goal of innovation and entrepreneurship education is to be applied in practice. It is obviously not enough to have a practical base in the university. It is necessary to actively expand the practice base outside the school in order to be closer to the society. actual. For the broadening of the out-of-school innovation and entrepreneurship education base, the author proposes that the application-oriented undergraduate colleges should actively seek and integrate all resources, give full play to their own specialties, and do some extensions and explorations in school-enterprise cooperation and cooperation between industry, university and research institutes. Advantages are actively explored in economic and industrial dense areas such as local special economic development zones, industrial parks, and science and technology parks to create professional off-campus practice bases for students.

\section{Strengthen the Construction of Teaching Staff for Innovation and Entrepreneurship Education}

Innovation in the field of entrepreneurship education is an interdisciplinary, cross the comprehensiv e quality education, involved in economic management, engineering, government economy, venture investment, hatch, many aspects, such as management requires teachers professional structure diver sity.The innovation and entrepreneurship education requires teachers to have more cross-professional and cross-disciplinary requirements. Most of the application-oriented colleges and universities do not have full-time innovative entrepreneurship education teachers, and they urgently need to introduce high-quality full-time teachers. However, most of the application-oriented colleges and universities are running schools. Unfavorable, the teacher's treatment is not high, it is difficult to attract talents into the school. How to solve this problem, this paper believes that it is possible to adopt the means of "external introduction and internal training". First, the introduction of a number of core teachers to set up teaching groups, the entire school creative entrepreneurship courses planning, organization and effectiveness evaluation. Second, the 
relevant professional teachers in the school are hired to undertake the special teaching of "legal", "economic" and "mental" modules. Thirdly, selecting a group of young teachers in the school to train them in the knowledge, skills, and teaching methods of innovation and entrepreneurship education, so that they are proficient in the basic methods and techniques of innovation and entrepreneurship education, and become a stable force in the school's innovation and entrepreneurship education. .Through the establishment of a special part-time union, a sufficient number of innovative entrepreneurship education teachers team to promote the school innovation and entrepreneurship education development.

\section{References}

[1] Jiahua Li, Xudong Lu. Integrating innovation and entrepreneurship education into college personnel training system. China Higher Education. 2010,12. 9-11;

[2] Shushan Ma. Application-oriented Undergraduate Education: The New Task of Local Universities in the 21st Century[J]. Journal of Changzhou Institute of Technology, 2010(1);

[3] Chenghui He, Qun Su. Approaches to the cultivation of students' ability in applied universities[J]. China Higher Education Research, 2002(3);

[4] Tao Zhang. Entrepreneurship Education [M]. Beijing: Mechanical Industry Press, 2007;

[5] Xiaohui Ma. Entrepreneurial university entrepreneurship education goals, characteristics and practice path [J]. Chinese Higher Education Research, 2013, (7);

[6] Baohua Cheng. Research on Undergraduate College Students' Innovation and Entrepreneurship Education: A Case Study of Chenzhou University[D]. Shandong Normal University. 2015

[7] Xiao LIU, Yong-ming HUANG. Discussion on the Construction of College Students' Entrepreneurial Education Teachers[J].Journal of Heilongjiang College of Education,2013(1) 